\title{
Estomatite Vesicular Alagoas (VSA) em tilápia nilótica (Oreochromis niloticus). Possível implicação epidemiológica*
}

\section{Vesicular Stomatitis Alagoas (VSA) in tilapia nilotica (Oreochromis niloticus). Possible epidemiological concern}

\author{
Carlos Henrique de Azeredo-Lima, ${ }^{\star \star}$ Claudio de Moraes Andrade, ${ }^{\star *}$ Francisco Benedito Rangel Filho, ${ }^{* \star}$ \\ Francisco Gerson Araújo***
}

\begin{abstract}
Resumo
Foram realizadas inoculações experimentais do vírus da Estomatite Vesicular Alagoas (VSA) em tilápia nilótica (Oreochromis niloticus), pela via intraperitoneal e por imersão em suspensão viral, com o objetivo de verificar se 0 mesmo se replicava neste sistema hospedeiro e se o vírus era eliminado na água, o que poderia representar um importante papel no ciclo epidemiológico da virose. Os peixes foram dispostos em grupos testemunhos e inoculados com suspensão de vírus VSA, tanto pela via intraperitoneal quanto por imersão. Foram observadas alterações anatomopatológicas em órgãos da cavidade abdominal e cérebro. Esses órgãos e a água do aquário foram inoculados em células $\mathrm{BHK}_{21}$ e observados a presença de efeito citopático característico dos vírus pertencentes a este gênero. A segunda passagem do vírus em peixes confirmou as lesões encontradas anteriormente e o isolamento em novas inoculações em cultivo celular. Os resultados sugerem que a tilápia é sensível ao VSA nas duas vias de inoculação, elimina formas infectantes do vírus na água, podendo representar um importante elo na cadeia epidemiológica da estomatite vesicular.
\end{abstract}

Palavras-chave: Epidemiologia; estomatite; vesicular; Alagoas; tilápia.

\section{Introdução}

A ecologia do vírus da estomatite vesicular (VSV) é pouco conhecida e apresenta muitos aspectos obscuros a serem preenchidos com relação ao ciclo básico da infecção (Acha, Szyfres, 1986).

Nas áreas tropicais endêmicas encontramos um grande número de animais silvestres reagindo positivamente a pesquisas sorológicas, não tendo sido demonstrado se estes animais são reservatórios naturais. A alta taxa de animais silvestres reativos, sem o envolvimento de animais domésticos, pode indicar que o vírus circula livremente dentro dessa população (Zuluaga, Yuill, 1979).

A literatura registra que os ciclos dessa doença segue o curso de águas e, freqüentemente, acomete o gado bovino e eqüino que pasta em áreas alagadas onde a presença de lagos é mais comum que planícies abertas. Em contrapartida, as áreas desérticas e planícies sem árvores servem como barreiras para conter a disseminação da doença (Bishop, 1979).

É citado na literatura uma semelhança do perfil polipeptídico do Pike Fry Rhabdovirus (PFR) com o VSV-Indiana (Kinkelin et al., 1974 ; Hill, B. J. 1975) o que poderia indi- car uma relação antigênica entre os dois vírus. Com base nesta relação foi realizado o presente trabalho, que visava investigar o envolvimento dos peixes como reservatório ou amplificador de vírus da estomatite vesicular na natureza.

\section{Material e métodos}

Vírus-Estomatite Vesicular Alagoas (Andrade, 1974) pertencente à coleção do Centro Pan-americano de Febre Aftosa, com título 107.5/0,1ml (Reed, L. J., Muench, H. 1938). Meio de cultura-MEM-Glasgow adicionado, no momento do uso, de glutamina (L-glutamina, Gibco Laboratories), penicilina (Penicilina G Potássica (benzilpenicilina potássica) Laboratório Wyeth Ltda.), estreptomicina (Sulfato de estreptomicina) Laboratório Wyeth Ltda.), fungizona (Fungizonâ (Anfotericina B) Gibco Laboratories) e soro bovino a $10 \%$.

Célula - $\mathrm{BHK}_{21}$ (Baby Hamster Kidney), clone 13, cedida pelo Centro Pan-americano de Febre Aftosa do Rio de Janeiro.

Água -A água utilizada no experimento é a mesma distribuída para toda a região do Grande Rio, mantida sob

*Desdobramento de tese de Mestrado em Medicina Veterinária.

**Laboratório de Viroses Veterinárias, Instituto de Veterinária, Universidade Federal Rural do Rio de Janeiro.

***Departamento de Piscicultura Instituto de Zootecnia, Universidade Federal Rural do Rio de Janeiro, Km 47 da antiga. Rodovia Rio-São Paulo, CEP 23851-970, Seropédica, RJ, Brasil. 
aeração constante, com o objetivo de eliminar, por evaporação, o cloro adicionado à mesma, bem como favorecer a oxigenação, só sendo transferida para os aquários após 48 hora de aeração.

Peixe - Tilápia nilótica (Oreochromis niloticus), com peso médio de 5,6g, oriundas do Departamento de Piscicultura do Instituto de Zootecnia da UFRRJ.

Inóculo - Os peixes do $1^{\circ}$ experimento (IV1) foram inoculados com suspensão do vírus em MEM-Glasgow a 1/10 (v/v). O inóculo do Grupo Testemunho de Diluição (TD) foi o próprio MEM-Glasgow.

No $2^{\circ}$ experimento o inóculo do grupo inoculado com VSA de 2a passagem (IV2) foi preparado a partir dos órgãos dos peixes do grupo IV1 triturado, diluído a 1/10 e centrifugado a $1000 \times \mathrm{g}$ por 5 minutos a $5^{\circ} \mathrm{C}$. O sobrenadante foi diluído em MEM-Glasgow a $1 / 10$, dando origem à solução de inoculação. $\mathrm{Na}$ inoculação do grupo vírus-água (IVA) foi utilizada a água do aquário do grupo IV diluída na proporção de 1/10 em MEM-Glasgow.

Inoculação em células - Os órgãos dos peixes de cada grupo foram triturados, diluídos em MEM-Glasgow na proporção de $1 / 10(p / v)$ e centrifugados a $1000 \times$ g por 5 minutos a $5^{\circ} \mathrm{C}$. Os sobrenadantes foram novamente diluídos com MEM-Glasgow de 1/50 e 1/500, com a concentração de antibiótico duas vezes superior à utilizada no cultivo celular. Os tubos com cultivo celular foram inoculados $0,1 \mathrm{ml}$ de solução para cada tubo.

Inoculação intraperitoneal - Os peixes foram inoculados $0,1 \mathrm{ml}$ de cada inóculo, no ponto médio entre a região genital e a linha média entre as nadadeiras peitorais.

Imersão (I) - Os peixes foram infectados por imersão através da adição de $5 \mathrm{ml}$ da suspensão viral de referência à água do aquário com apenas 2 litros. Após uma hora, o aquário teve seu nível d'água restaurado seguindo-se, posteriormente, a mesma rotina dos outros aquários.

Cultivo celular - No momento da inoculação do material oriundo dos peixes, o meio de crescimento foi desprezado e adicionado $0,1 \mathrm{ml}$ das diluições $1 / 50$ e 1/500 de cada grupo e mais a água do aquário do grupo inoculado com VSA. Após a inoculação nas células, aguardou-se 1 hora para a adsorsão do vírus à célula, agitando-se, suavemente, a cada 15 minutos, completando-se o volume com $0,9 \mathrm{ml}$ de meio de manutenção (MEM-Glasgow com $2 \%$ de soro bovino).

Foram utilizados 5 tubos de células por diluição e por dia, totalizando 50 tubos por grupo e 15 tubos para os controle de células e do vírus. A leitura era realizada a cada 24 horas a partir do momento da inoculação, durante cinco dias.

10 Experimento - Os peixes foram distribuídos em seis aquários, sendo dois aquários para cada grupo. O grupo testemunho (T) e TD eram constituídos por 30 peixes cada e o grupo IV1 por 40 peixes.

$2^{\circ}$ Experimento $-O 2^{\circ}$ experimento foi a repetição do primeiro, com o acréscimo dos grupos IVA e IV2 coṃ 40 peixes cada grupo e do grupo I com 15 peixes.

Esquema de colheita de material - (12 experimento) No primeiro dia (dia zero), foram coletados seis peixes do grupo T para inoculação em cultivo celular. Neste momento foi inoculado com a suspensão do VSA o grupo IV1 e com MEM-Glasgow modificado o grupo TD.

Após 24 horas e até $05^{\circ}$ dia foram coletados, diariamente, três peixes dos grupos T e TD, seis peixes do grupo IV1 e $5 \mathrm{ml}$ de água de cada aquário, para inoculação em cultivo celular.

A mesma rotina foi seguida no $2^{\circ}$ experimento.

Colheita de material - Na necrópsia foram retirados os órgãos abdominais e o cérebro. O material coletado fornecia, em média, $1,5 \mathrm{~g}$ de material, por peixe, coletando-se dois peixes de cada grupo.

O material era triturado e suspenso em MEM-Glasgow na proporção de $1 / 10(p / v)$, sendo considerado como material não diluído e estocado a $-20^{\circ} \mathrm{C}$, até o momento do uso.

A água de cada aquário era coletada no momento da captura dos peixes, retirando-se $5 \mathrm{ml}$ de cada aquário. As amostras de água coletadas de aquários do mesmo grupo eram homogeneizadas em um frasco estéril, estocandose apenas $5 \mathrm{ml}$ desta mistura em congelador a $-20^{\circ} \mathrm{C}$.

\section{Resultados}

Comportamento - Não foi observada nenhuma alteração comportamental dos peixes, durante os dois experimentos.

Alterações anatomopatológicas - As observações das alterações anatomopatológicas foram realizadas com 0 auxílio de lupa, logo após o sacrifício dos peixes.

Grupos T e TD - Estes grupos não apresentaram alterações anatomo-patológicas que pudessem ter sido ocasionadas pela inoculação ou pelo diluente (Figura 1).

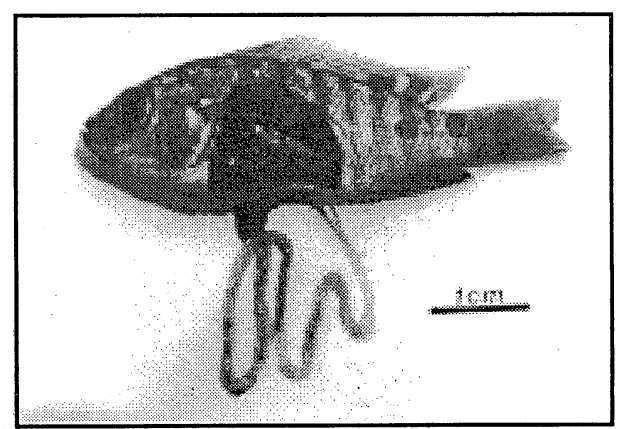

Figura 1: Tilápia normal

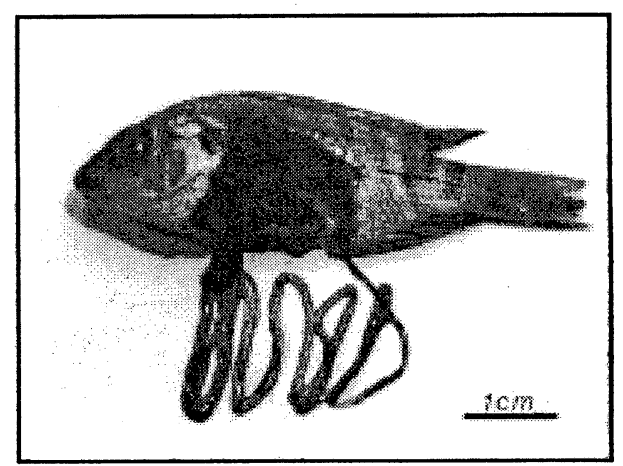

Figura 2: Hiperemia da $1^{\mathrm{a}}$ porção do tubo diestivo 
Demais grupos - As alterações anatomopatológicas ocorreram a partir do primeiro dia, aumentando de intensidade a cada dia, observando-se hiperemia da primeira porção do tubo digestivo (Figura 2) com congestão de vasos, evoluindo para áreas de petéquias e presença de edema ao longo do tubo digestivo; vasos mesentéricos congestos; fígado congesto com áreas de formação de petéquias; vesícula biliar repleta, de coloração verde-escura intensa a hemorrágica (Figura 2).

Isolamento em célula - As células mostraram efeito citopatogênico compatível com o que correu no controle do vírus.

Os Grupos T e TD, nos dois experimentos, não apresentaram ECP, o mesmo ocorrendo com o controle de célula.

1 experimento - As células inoculadas com suspensão dos órgãos dos peixes do Grupo IV1 apresentaram 18 tubos positivos no primeiro dia, 5 no segundo dia, 24 no terceiro dia, 20 no quarto dia e 25 no quinto dia. O total de tubos positivos para a diluição $1 / 500$ foi de 37 e para a diluição de $1 / 50$ foi de 55 .

As células inoculadas com diluição da água do Grupo IV1 apresentam 14 tubos positivos no primeiro dia, 17 no segundo dia, 12 no terceiro dia, 20 no quarto dia e 21 no quinto dia. O total de tubos positivos para a diluição 1/500 foi de 43 e para a diluição de $1 / 50$, foi de 41 .

$2^{\circ}$ experimento - As células inoculadas com suspensão dos órgãos dos peixes do grupo IV1 apresentaram 15 tubos positivos no primeiro dia, 31 no segundo dia, 23 no terceiro dia, 30 no quarto dia e 24 no quinto dia. O total de tubos positivos para a diluição $1 / 500$ foi de $66 \mathrm{e}$, para a diluição de 1/50 foi de 57 .

As células inoculadas com suspensão dos órgãos dos peixes do grupo IV2 apresentaram 36 tubos positivos no primeiro dia, 34 no segundo dia, 39 no terceiro dia, 39 no quarto dia e 30 no quinto dia. O total de tubos positivos para as duas diluições foi de 89.

As células inoculadas com suspensão dos órgãos dos peixes do grupo 1 apresentaram 7 tubos positivos no primeiro dia, 18 no segundo dia, 17 no terceiro dia, 20 no quarto dia e 17 no quinto dia. O total de tubos positivos para a diluição $1 / 500$ foi de 41 e, para a diluição de $1 / 50$, foi de 38 .

Tabela 1: Resultado do isolamento em célula dos grupos inoculados com suspensão de vírus (IV) e de órgãos (IV2)

\begin{tabular}{|c|c|c|c|c|c|c|}
\hline \multirow{4}{*}{ Dia } & \multicolumn{3}{|c|}{$1^{\circ}$ Experimento } & \multicolumn{3}{|c|}{$2^{2}$ Experimento } \\
\hline & \multicolumn{3}{|c|}{$\begin{array}{l}\text { Inoculado com suspensão de } \\
\text { vírus (IV) }\end{array}$} & \multicolumn{3}{|c|}{$\begin{array}{l}\text { Inoculado com suspensão de órgão } \\
\text { (IV2) }\end{array}$} \\
\hline & \multicolumn{2}{|c|}{ Diluição } & \multirow[b]{2}{*}{ TOTAL } & \multicolumn{2}{|c|}{ Diluição 1/ } & \multirow[b]{2}{*}{ TOTAL } \\
\hline & $1 / 500$ & $1 / 50$ & & $1 / 500$ & $1 / 50$ & \\
\hline $1^{0}$ & 10 & 8 & 18 & 17 & 19 & 36 \\
\hline $2^{-0}$ & 2 & 3 & 5 & 17 & 17 & 34 \\
\hline $3^{0}$ & 6 & 18 & 24 & 20 & 19 & 39 \\
\hline $4^{-0}$ & 11 & 9 & 20 & 17 & 22 & 39. \\
\hline $5^{0}$ & 8 & 17 & 25 & 18 & 12 & 30 \\
\hline TOTAL & 37 & 55 & 92 & 89 & 89 & 178 \\
\hline
\end{tabular}

As células inoculadas com suspensão dos órgãos dos peixes do grupo IVA apresentaram 34 tubos positivos no primeiro dia e 17 no segundo dia; no terceiro dia a amostra foi perdida, 39 no quarto dia e 27 no quinto dia. O total de tubos positivos para a diluição $1 / 50$ foi de 62 tubos e, para a diluição de $1 / 500$, foi de 55 tubos.

Tabela 2: Resultado do isolamento em célula da água do aquário do grupo Inoculado com suspensão de vírus (IV) e da inoculação nos peixes de com a mesma

\begin{tabular}{c|c|c|cc|c|c}
\hline \multirow{4}{*}{ Dia } & \multicolumn{3}{|c}{$1^{\circledR}$ Experimento } & \multicolumn{3}{c}{$\begin{array}{c}2^{0} \text { Experimento } \\
\text { inoculado com } \\
\text { suspensão de vírus }\end{array}$} \\
\cline { 2 - 7 } & \multicolumn{3}{|c|}{$\begin{array}{c}\text { Diluição 1/ } \\
\text { Diluados com a água } \\
\text { do grupo IV }\end{array}$} \\
\cline { 2 - 7 } & 500 & 50 & TOTAL & 500 & 50 & TOTAL \\
\hline $1^{\circ}$ & 6 & 8 & 14 & 18 & 16 & 34 \\
\hline $2^{\circ}$ & 9 & 8 & 17 & 9 & 8 & 17 \\
\hline $3^{\circ}$ & 9 & 3 & 12 & - & - & - \\
\hline $4^{\circ}$ & 10 & 10 & 20 & 14 & 25 & 39 \\
\hline $5^{\circ}$ & 9 & 12 & 21 & 21 & 6 & 27 \\
\hline TOTAL & 43 & 41 & 84 & 62 & 55 & 117 \\
\hline
\end{tabular}

Tabela 3: Total de tubos positivos do grupo 1, do segundo experimento, por diluição, em cada dia do experimento

\begin{tabular}{c|c|c|c}
\hline \multirow{2}{*}{ Dial } & \multicolumn{2}{|c|}{ Diluição } & \\
\cline { 2 - 4 } & $1 / 500$ & $1 / 50$ & Total \\
\hline $1^{\circ}$ & 3 & 4 & 7 \\
\hline $2^{\circ}$ & 9 & 9 & 18 \\
\hline $3^{\circ}$ & 9 & 8 & 17 \\
\hline $4^{\circ}$ & 11 & 9 & 20 \\
\hline $5^{\circ}$ & 9 & 8 & 17 \\
\hline TOTAL & 41 & 38 & 79 \\
\hline
\end{tabular}

Os Rhabdovírus de peixes produzem, de um modo geral, doenças hemorrágicas que podem vir acompanhadas de edema generalizado, determinando o aparecimento de ascite, exoftalmia e, em alguns casos, hidrocefalia, necrose hematopoiética e petéquias, distribuídas no parênquima dos órgãos internos, musculatura esquelética e nadadeiras. (Wolf, 1988, Moeller Jr., 1995). 
Em animais, principalmente eqüinos, os Rhabdovírus do gênero Vesiculovirus produzem uma enfermidade com patologia bastante distinta, desenvolvendo enfermidade do tipo vesicular (Bishop, 1980).

O vírus da estomatite vesicular Alagoas produziu lesões do tipo hemorrágico, no aparelho digestivo e presença de conteúdo hemorrágico na vesícula biliar, não sendo observada mortalidade, o que poderia ocorrer devido a fatores diversos como a espécie do peixe, adaptação do vírus e duração do experimento, entre outros, muito embora, na necropsia, tenhamos notado alterações hemorrágicas.

As lesões anatomopatológicas produzidas pelo VSA, no grupo da imersão do peixe em suspensão viral ou naqueles inoculados por via intraperitoneal, não apresentaram diferenças.

Em cultivo celular o aparecimento de ECP, com material oriundo dos grupos inoculados por via intraperitoneal, nas primeiras 24 horas foi considerado de pouco valor por acreditarmos que o mesmo ocorria, provavelmente, devido a um resíduo da inoculação.

No segundo dia este valor sofreria um decréscimo, o que pareceu indicar que os valores obtidos no dia anterior foram resultantes dos vestígios da inoculação e que as partículas virais neste dia ainda não se encontravam em sua plena forma infectante.

Os valores máximos de produção de ECP foram encontrados nos terceiro e quarto dias pós inoculação, decrescendo no quinto dia, sendo este fato encarado como um fator confirmatório da replicação do vírus no organismo dos peixes. O decréscimo na produção de ECP pode ter sido ocasionado pela intervenção das defesas imunológicas do peixe e/ou que a replicação viral estaria se adequando para uma faixa de replicação ideal.

O grupo que sofreu imersão em suspensão viral apresentou uma produção de ECP de förma gradativa, no primeiro dia apresentando valores abaixo da média do grupo. No segundo e terceiro dia os valores foram relativamente semelhantes e acima da média, indicando que ocorreu replicação no peixe de uma forma mais efetiva, o que ocorreria por contato na forma natural. O valor máximo foi obtido no quarto dia indicando o pico da replicação viral, retornando no dia seguinte ao nível do terceiro dia.

A adaptação do vírus ao novo sistema foi observada na comparação do grupo IV1 com o grupo IV2, inoculado com suspensão oriunda de passagem anterior em peixes.

A água do aquário do grupo IV1 do primeiro experimento foi coletada diariamente para verificar se os peixes eliminavam vírus na água e em quantidade suficiente para pro- duzir uma reinfecção, já que $50 \%$ da água do mesmo era trocada a cada dia. Os resultados positivos deste grupo apareceram logo no primeiro dia atingindo um total de 14, que pode ser atribuído a eliminação do vírus pelo peixe. Nos quatros dia subsequentes foram observados, respectivamente, um total de 17, 12, 20 e 21 positivos.

Comparando-se esses valores com o resultado obtido no grupo IV1, do primeiro experimento, observa-se que a quantidade de positivos para a água do aquário do grupo IV1 correspondia a quantidade de positivos do grupo IV1, significando que havia uma correlação entre o aumento da positividade e negatividade entre os grupos.

O grupo IVA era constituído pelos peixes inoculados com a água do grupo IV1, do primeiro experimento. A quantidade de positivos encontrada foi semelhante àquela encontrada no grupo IV2.

\section{Conclusões}

A tilápia se mostrou sensível ao VSA, tanto por inoculação via intraperitoneal quanto por imersão em solução com vírus.

Nas duas vias utilizadas para infecção dos peixes, intraperitoneal e imersão, os inóculos preparados a partir de vísceras mostraram-se positivos quando inoculados em cultivos celulares.

O inóculo preparado a partir da água do grupo IV 1 do $1^{\circ}$ experimento e inoculado em cultivos celulares, revelou a presença de ECP positivo, o que demonstra que os peixes infectados eliminam vírus para o meio ambiente.

Durante o período do experimento, 5 dias, não foi observado nenhuma mudança de comportamento apesar das alterações anatomopatológico. Este período pode ser considerado uma fase bastante aproximada ao período total de incubação, visto que, o vírus se adaptou, replicou e mantevese relativamente estável nos últimos dias do experimento.

As alterações anatomopatológicas dos órgãos internos encontradas são semelhantes às patologias produzidas, de um modo geral, pelos Rhabdovirus de peixes (Pike Fry Rhabdovirus, Spring Viremia of Carp, Infectious hematopoietic Necrosis virus e Infectious hematopoietic Necrosis virus).

Os resultados encontrados quer na infecção dos peixes quer nos cultivos celulares, associados as lesões anatomopatológicas, efeito citopático e a sorologia do vírus empregado no presente trabalho, sugerem que os peixes desempenham um importante papel na cadeia epidemiológica da Estomatite Vesicular.

\section{Abstract}

Experimental infections were reproduced with the virus of Vesicular Stomatitis Alagoas (VSA) in Nile Tilapia (Oreochromis niloticus), through intraperitoneal inoculations and bath in infective homogenate, with the purpose to determinate if this virus was able to replicate in this host and if able to eliminate the virus into the water which could represent an important 
feature in the epidemiology of the viruse. During the experiments, fishes were distributed in witness groups and inoculated group with homogenate viral suspension of VSA. From these groups were observed anatomypathology alterations and collected abdominal organs, brain and water form the aquariums to prepare suspension for passages and inoculation in cell culture of $\mathrm{BHK}_{21}$. The collected abdominal organs were standard histopathological method too (not available yet). The cell culture showed the characteristic citophatic effect produced by this virus genus. The virus passage in the host system was demonstrated, by anatomyphatology finds and repetition of same alterations seen before. It could means that the virus had an adaptation to the fish. The results indicated that Nile Tilapia is sensible to VSA virus through both inoculations, it eliminate infective particles of virus into the water and for all these reasons, it could take a important place in the epidemiology sequence of Vesicular Stomatitis.

Keywords: Epidemiology; stomatitis; vesicular; Alagoas; tilapia.

\section{Referências bibliográficas}

ACHA, P. N., SZYFRES, B. Zoonosis y enfermedades transmisibles comunes al hombre y a los animales. Publicación Científica n. 503. Primera Edición. Organización Panamericana de la Salud. Washington, D.C., 1986.

ANDRADE, C. M. Estomatite Vesicular no Brasil. 1974. (Tese) Livre Docência em Virologia. - Instituto de Microbiologia Prof. Paulo de Góes da Universidade Federal do Rio de Janeiro. 1974.

BISHOP, D. H. L. Rhabdoviruses. Ed. CRC Press, Inc. Boca Raton, Florida. USA, 1980.

de KINKERLIN, P., le BERRE, LENOIR, G. Rhabdovirus des poissons. I. Propriétés in vitro de virus de la maladie rouge de l'alevin de brochet. Ann Microbiol. (Paris) n. 125A, p. 93-111, 1974.
HILL, B. J., UNDERWOOD, B. O., SMALE, C. J., BROWN, F. 1975. Physical=chemical and serological characterization of five rhabdoviruses infecting fish. J. Gen. Virol. n. 27, p. 369-378.

MOELLER JR, R. B. Diseases of Fish. Armed Forces Institute of Pathology. Washington, D.C., USA, 1995.

REED, L. J., MUENCH, H. A simple method of estimating fifty per cent endpoint. Amer. J. Hyg. n. 27, p. 493-497, 1938.

WOLF, K. Fish Viruses and Fish Viral Diseases. Comstock Publishing Associate. Cornell University Press. Ithaca and London, 1988.

ZULUAGA, F. N., YUILL, T. M. 1979. Estudios ecológicos de los vírus de estomatite vesicular en Antioquia, Colômbia. Bol. of Sanit. Panam, n. 87, p. 389-404.

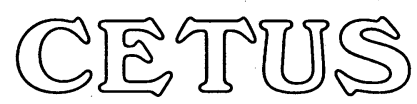

NIKON (Japão)

Distribuidor Nacional

Cetus Hospitalar Comércio e Representações Ltda.

Microscópios Biológicos e Industriais - Espectofotômetros Deonizadores - Kits para bioquímica - Contador de Células

Assistência Técnica

Rua Lopes Trovão, 75 - Benfica

20920-310 - Rio de Janeiro - RJ

Tel.: (21) 568-9345

Fax: (21) 264-3628

E-mail: cetus@abeunet.com.br 